\title{
Cervical cerclage complications: eight years of experience
}

\author{
Ayşe Karahasanoğlu', Işıl Uzun Çilingir², Ayşegül Deregözü', Hale Akin', \\ Zilal Hocagil', Oğuz Yücel' \\ ${ }^{1}$ Clinics of Obstetrics \& Gynecology, Sïleymaniye Training and Research Hospital, Istanbul, Turkey \\ ${ }^{2}$ Clinics of Obstetrics \& Gynecology, Acıbadem Hospital, İstanbul, Turkey
}

\begin{abstract}
Objective: The aim of this study is to analyze cervical cerclage cases in our clinic retrospectively and to evaluate the complications associated with the procedure.

Methods: The patients who undergone cervical cerclage operation between April 2004 and December 2012 at Süleymaniye Training and Research Hospital were included in the study. The data of patients, complications of the procedure, week of gestation at delivery, delivery type and postnatal complications were analyzed retrospectively.

Results: Cervical cerclage suture was applied to 100 patients. While the rate of emergency cases was $8.0 \%(n=8)$, the rate of elective cases was $68 \%(n=68)$ and the rate of prophylactic cases was $24 \%(n=24)$. Mean week of gestation was $33.55 \pm 6.06$. While $31 \%(n=31)$ of the deliveries were preterm, 69\% $(\mathrm{n}=69)$ of them were term. Mean delivery week was $27.8 \pm 7.9$ in emergency group, $33.9 \pm 5.8$ in elective group and $34.2 \pm 5.1$ in prophylactic group. The membranes were ruptured (PPROM) after cerclage in $10(10 \%)$ patients. While pregnancy was lost in nine patients at the early period after the rupture of membrane, pregnancy was lost in one patient after three weeks. One of these patients developed fever and chorioamnionitis. When the complications were analyzed, it was seen that the rate of complications in emergency group was statistically and significantly higher than two other groups. $(\mathrm{p}=0.005$ and $\mathrm{p}<0.1)$.

Conclusion: The rates of preterm labor were relatively higher in our cases, and other complications were seen rarely (chorioamnionitis, fever, cervical laceration). Compared to elective and prophylactic cerclage groups, the rate of preterm labor and complications were significantly higher in the emergency cerclage group.
\end{abstract}

Keywords: Cerclage, preterm labor.

\section{Özet: Servikal serklaj komplikasyonları: Sekiz yıllık deneyim}

Amaç: Bu çalışmanın amacı, kliniğimizde yapılmış servikal serklaj olgularını retrospektif olarak analiz etmek ve işleme bağlı olarak gelişmiş olan komplikasyonları değerlendirmektir.

Yöntem: Nisan 2004 ile Aralık 2012 tarihleri arasında Süleymaniye Ĕgitim ve Araştırma Hastanesi'nde servikal serklaj operasyonu geçiren hastalar çalışmaya alındı. Hastaların özellikleri, işlemin komplikasyonları, doğumdaki gebelik haftası, doğum şekli ve postnatal komplikasyonlar retrospektif olarak incelendi.

Bulgular: Yüz hastaya servikal serklaj suturu konuldu. Acil olguların oranının \% $8.0(\mathrm{n}=8)$ olduğu gözlenirken, elektif olguların \%68 $(\mathrm{n}=68)$, profilaktik olguların ise $\% 24(\mathrm{n}=24)$ oranında olduğu saptandı. Ortalama doğum haftası $33.55 \pm 6.06$ hafta idi. Doğumların \%31'i (n=31) preterm, \%69'u ( $n=69)$ ise term olarak gerçekleşti. Ortalama doğum haftası acil grupta $27.8 \pm 7.9$ iken elektif grupta $33.9 \pm 5.8$ ve proflaktik grupta $34.2 \pm 5.1$ hafta idi. On (\%10) hastada serklaj sonrası membranlar rüptüre (PPROM) oldu. Dokuz hastada membran rüptürü sonrası erken dönemde gebelik kaybı gelişirken, bir hastada üç hafta sonra gebelik kaybı gelişti. Bu hastaların birinde ateş ve koryoamniyonit gelişti. Doğum sırasında iki hastada servikal laserasyon oluştu. Komplikasyonlar incelendiğinde; acil grupta komplikasyon gözlenme oranının diğer iki gruptan istatistiksel olarak anlamlı düzeyde daha yüksek olduğu gözlendi $(\mathrm{p}=0.005$ ve $\mathrm{p}<0.1)$.

Sonuç: Bizim sonuçlarımızda erken doğum oranları nispeten yüksek seyrederken, diğer komplikasyonlar (koryoamniyonit, ateş, servikal laserasyon) nadir görüldü. Acil serklaj grubunda, elektif ve profilaktik serklaj grubuna nazaran, erken doğum oranları ve komplikasyonlar açısından anlamlı bir yükseklik saptandı.

Anahtar sözcükler: Serklaj, erken doğum.

\author{
Correspondence: Dr. Işı1 Uzun Çilingir, MD. Acıbadem Hastanesi Kadın \\ Hastalıkları ve Doğum Kliniği, İstanbul, Turkey. \\ e-mail: isiluzu@gmail.com
}

Received: September 1, 2013; Accepted: March 31, 2014
Available online at: www.perinataljournal.com/20140222010 doi: $10.2399 /$ prn.14.0222010 QR (Quick Response) Code: 


\section{Introduction}

Insufficiency of cervix for maintaining pregnancy until the term is called as cervical insufficiency or incompetent cervix. This condition is observed in $1 \%$ of all pregnant women. Nonetheless, the rate of cervical insufficiency increases up to $8 \%$ in patients who had losses previously at second and third trimesters. ${ }^{[1]}$

The significance of diagnosis and treatment of preterm labor on improving gestational outcomes have been presented clearly in many studies. ${ }^{[2,3]}$

Cervical cerclage suture, despite the debates on its advantages, has been used widely in pregnant women who have high risk in terms of preterm labor, and especially in pregnant women who previously had second trimester pregnancy losses. In cases indicating cervical insufficiency, it creates mechanical tension and also serves as a barrier. ${ }^{[4]}$ However, cervical cerclage is an invasive procedure and has some risks. Among the wellknown complications of cervical cerclage, there are preterm labor, chorioamnionitis and maternal infection. ${ }^{[5]}$ Cervical scar development and associated cervical lacerations are among the reported complications. In this study, we retrospectively reviewed our own cases through eight years of experience, and evaluated the rates of these complications in our cases.

\section{Methods}

The study was designed between April 2004 and November 2012 in the Clinics of Obstetrics \& Gynecology, Süleymaniye Training and Research Hospital. One-hundred patients who had cervical cerclage during this period were included in the study. The cerclage procedure was applied between 12 and 24 weeks of gestation. In all cases, McDonald cerclage suture with mersilene tape was applied under general anesthesia. All cases were administered prophylactic antibiotics (1 g IV cefazolin per 8 hours for postoperative 24 hours). Also, tocolytic application $(4 \times 20 \mathrm{mg}$ nifedipine following 30 $\mathrm{mg}$ oral use as loading dose) was carry out to all cases during postoperative 24 hours. After the procedure, bed rest was recommended for three days.

The diagnosis of patients who had cerclage suture by being diagnosed cervical insufficiency differs according to the groups. While the diagnosis of elective group was established according to the history of one or more pregnancy losses at second trimester, it was established in prophylactic group by serial measurements of cervical length. In this group, pregnant women who had clinical findings and cervical length at or below $25 \mathrm{~mm}$ were included in the study. In all cases, cervical length was measured transvaginally. Characteristics of the patients, complications of the procedure, week of gestation at delivery, delivery type and postnatal complications were evaluated retrospectively.

For statistical analysis, we used NCSS (Number Cruncher Statistical System) 2007\&PASS (Power Analysis and Sample Size) 2008 Statistical Software (NCCS, Kaysville, UT, USA). When analyzing study data, we used Kruskal-Wallis test for comparing three and more groups not displaying normal distribution in quantitative data and Mann-Whitney $U$ test for determining the group displaying difference as well as definitive statistical methods (Mean, Standard Deviation, Median, Frequency, Rate, Minimum, and Maximum). In the comparison of qualitative data, we used Pearson's chi-square test and Fisher-Freeman-Halton's exact test. Significance was accepted as $\mathrm{p}<0.01$ and $\mathrm{p}<0.05$.

\section{Results}

The ages of the cases were ranging between 15 and 44 and the mean age was $31.70 \pm 5.77$. While the rate of emergency cases was $8 \%(n=8)$, the rate of elective cases was $68 \%(n=68)$, and the rate of prophylactic cases was 24\% ( $\mathrm{n}=24)$ (Fig. 1 and Table 1).

Cerclage was applied between 10.7 and 26.2 weeks, and the mean week was $18.8 \pm 4$. The median value for the week of cerclage was calculated as 21.7 weeks in the emergency group, 20.6 weeks in the elective groups and 15 weeks in the prophylactic group (Fig. 2 and Table 2).

Mean cervical length before cerclage was $16.6 \pm 8.84$ $\mathrm{mm}$. The median value was calculated as $5 \mathrm{~mm}$ for the emergency group, $16.5 \mathrm{~mm}$ for the elective group and $23 \mathrm{~mm}$ for prophylactic group. It was observed that the cervical lengths before cerclage were statistically and significantly higher than both the emergency group and elective group (respectively $\mathrm{p}=0.005, \mathrm{p}=0.003$ and $\mathrm{p}<0.01$ ) (Fig. 3 and Table 2).

While no complication is observed in $90 \%(n=90)$ of the cases, water break was observed in $10 \% \quad(n=10)$ of the cases, bleeding in $2 \% \quad(n=2)$ of cases, and chorioamnionitis with fever in $\% 1(n=1)$.

In $10(10 \%)$ out of 100 patients, premature rupture of membranes developed after cervical cerclage. In nine patients, pregnancy was lost after the rupture of membrane and three weeks later after the rupture in one patient. In one of these patients, fewer and 
chorioamnionitis developed. Fewer $\left(39^{\circ} \mathrm{C}\right)$ and leukocytosis $\left(\mathrm{WBC}=27 \times 10^{3}\right)$ were seen twenty-four hours after the procedure. All clinical and laboratory parameters of the patient were in normal limits before the cerclage. Pathological examination of the placenta was also compatible with chorioamnionitis. The patient who had chorioamnionitis and 4 out of 10 patients who had pregnancy loss were in the emergency cerclage group. Remaining three case in the same group delivered at 36 weeks of gestation and later, 1 emergency cerclage case delivered at 26 weeks of gestation.

In terms of the complications, it was seen that the rate for complications in the emergency group was significantly and statistically higher than other two groups $(\mathrm{p}=0.005$ and $\mathrm{p}<0.01)$. It was found that the rate for water break in the emergency group was significantly and statistically higher than other two groups ( $\mathrm{p}=0.005$ and $\mathrm{p}<0.01)$. In terms of the bleeding and chorioamnionitis with fewer, there was statistically no significant difference among the groups ( $\mathrm{p}>0.05)$.

Delivery weeks of the cases ranged between 14.4 and 39 weeks, and the mean week was $33.55 \pm 6.06$. Thirty-one percent $(n=31)$ of the deliveries were preterm, $69 \%(\mathrm{n}=69)$ of them were term. Mean delivery week was $27.8 \pm 7.9$ in the emergency group, $33.9 \pm 5.8$ in the elective group and $34.2 \pm 5.1$ in the prophylactic group (Table 2 ).

Forty-five (45\%) cases gave birth by cesarean section. When pregnancy loss was excluded, there was statistically no significant difference among the groups in terms of delivery types. Complications were seen in 14 (14\%) cases during or after the delivery. In two patients, cervical lacerations associated with advanced scar tissue were observed during delivery. Due to the incomplete expulsion of the placenta, Bumm curettage was applied to five patients. Extended antibiotic use after delivery was considered necessary in six patients. In terms the complications after delivery, the rate of premature rupture of membranes (PROM) in the emergency group was observed as statistically and significantly higher than the other two groups $(\mathrm{p}=0.038$ and $\mathrm{p}<0.05)$. Statistically no significant difference was observed among the groups in terms of the rates of any complication, Bumm curettage and chorioamnionitis with fewer ( $>0.05)$ (Table 2).

\section{Discussion}

Cervical cerclage is a treatment method which has been used for long years for preventing and treating preterm

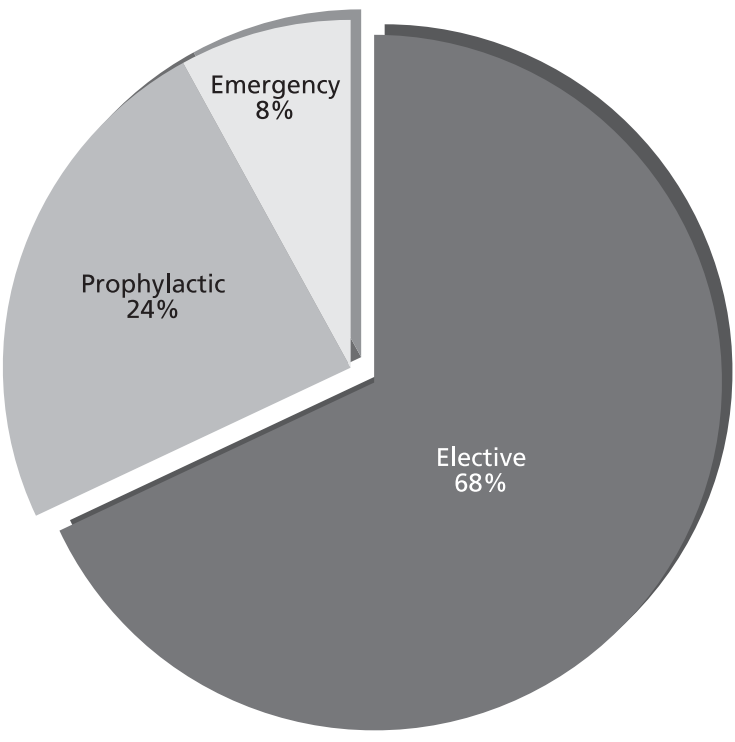

Fig. 1. Indication distribution.

labor. The literature provides conflicting results about its advantages and whether it really extends the period of pregnancy or not. There are publications reporting that

Table 1. Distributions of definitive characteristics.

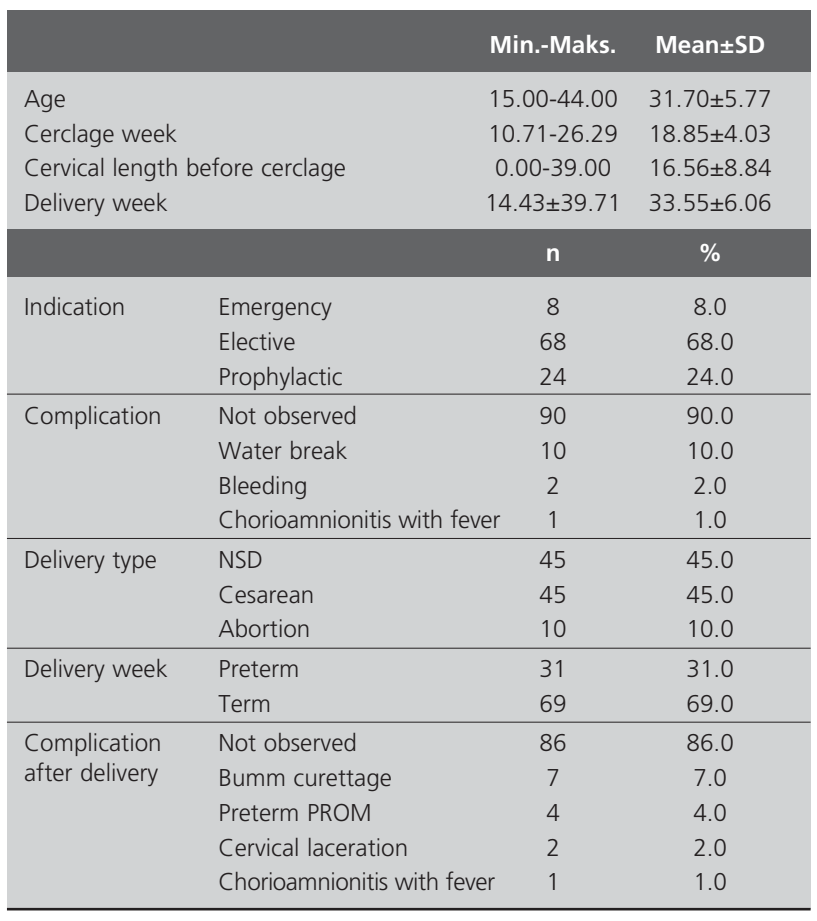

NSD: normal spontaneous delivery, PROM: premature rupture of membranes. 
cervical cerclage has no advantage over placebo in cases where fetal membranes prolapse to endocervical channel or $25 \%$ of total cervical length and in cases of which cervical length is measured as less than $2.5 \mathrm{~cm}$ or in cases where both conditions occur. ${ }^{[6]}$

However, more powerful studies showing the advantages of cerclage are also stand out. According to these studies, cervical cerclage decreases preterm labor, and prenatal mortality and morbidity. Especially in the cases of which cervical lengths were measured below $25 \mathrm{~mm}$ at second trimester, it prominently decreases delivery before 32 weeks of gestation, and perinatal morbidity and mortality. ${ }^{[7,8]}$ Therefore, we analyzed the cases that we applied cervical cerclage treatment in our clinic in order to prevent preterm labor. The primary purpose of cervical cerclage treatment is to prevent preterm labor. In our study, those who managed to proceed over 34 weeks of gestation were about $37.5 \%$ of the emergency cerclage group, $70.6 \%$ of the elective group, and $75 \%$ of the prophylactic group.

The rates in elective and prophylactic cerclage groups seem to be parallel with those reported in the studies published previously. However, our success rate in the emergency cerclage group was considered as low. ${ }^{[9,10]}$

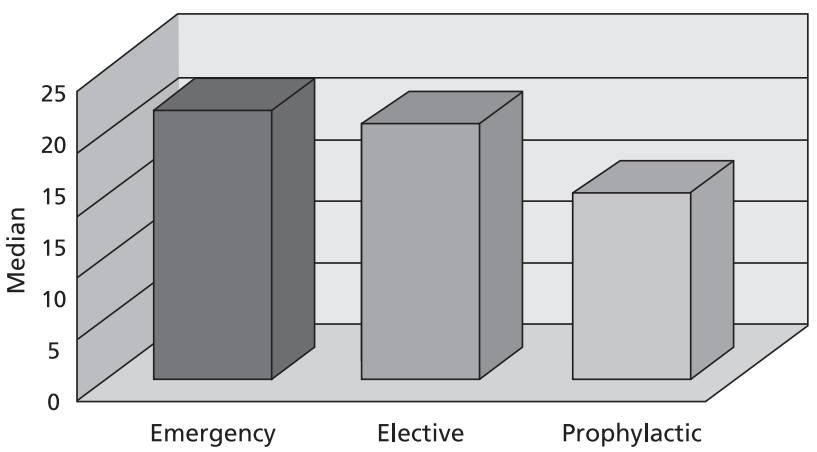

Fig. 2. Cerclage week distribution according to indication.

When it is decided to apply cervical cerclage to a patient, it is very significant to inform properly about the efficiency of the procedure, outcomes and complications that may develop. When considered in terms of medicolegal problems which have become more significant day by day, providing comprehensive information about especially complications seems to be crucial.

Complications after cervical cerclage such as rupture of membrane, chorioamnionitis, preterm labor, cervical laceration and damage in adjacent organs such

Table 2. Analyses about definitive characteristics according to the indication.

\begin{tabular}{|c|c|c|c|c|c|}
\hline & & $\begin{array}{c}\text { Emergency }(n=8) \\
\text { Mean } \pm \text { SD (Median) }\end{array}$ & $\begin{array}{c}\text { Elective ( } \mathrm{n}=68) \\
\text { Mean } \pm \text { SD (Median) }\end{array}$ & $\begin{array}{l}\text { Prophylactic }(n=24) \\
\text { Mean } \pm \text { SD (Median) }\end{array}$ & $\mathbf{p}$ \\
\hline Age & & $32.50 \pm 6.55(32.50)$ & $31.68 \pm 5.91(32.50)$ & $31.50 \pm 5.30(31.50)$ & a0.849 \\
\hline Cerclage week & & $21.16 \pm 1.45(21.79)$ & $19.57 \pm 3.95(20.64)$ & $16.05 \pm 3.49(15.00)$ & $\mathrm{a} 0.001$ * \\
\hline Cervical length before cerclage & & $9.13 \pm 8.97(5.00)$ & $15.55 \pm 7.56(16.50)$ & $21.92 \pm 9.65(23.00)$ & $a 0.002$ * \\
\hline \multirow[t]{2}{*}{ Delivery week } & & $27.86 \pm 7.96(25.07)$ & $33.96 \pm 5.88(36.57)$ & $34.27 \pm 5.10(35.64)$ & a0.105 \\
\hline & & n (\%) & n (\%) & n (\%) & \\
\hline \multirow[t]{4}{*}{ Complication } & Not observed & $4(50.0)$ & $63(92.6)$ & $23(95.8)$ & b0.005* \\
\hline & Water break & $4(50.0)$ & $5(7.4)$ & $1(4.2)$ & b0.005* \\
\hline & Bleeding & $1(12.5)$ & $1(1.5)$ & $0(0.0)$ & b0.210 \\
\hline & Chorioamnionitis with fever & $1(12.5)$ & $0(0.0)$ & $0(0.0)$ & b0.080 \\
\hline \multirow[t]{3}{*}{ Delivery type } & NSD & $2(25.0)$ & $32(47.1)$ & $11(45.8)$ & b0.553 \\
\hline & Cesarean & $2(25.0)$ & $31(45.6)$ & $12(50.0)$ & b0.496 \\
\hline & Abortion & $4(50.0)$ & $5(7.4)$ & $1(4.2)$ & b0.005* \\
\hline \multirow[t]{2}{*}{ Delivery week } & Preterm & $5(62.5)$ & $20(29.4)$ & $6(25.0)$ & c0.123 \\
\hline & Term & $3(37.5)$ & $48(70.6)$ & $18(75.0)$ & \\
\hline \multirow[t]{5}{*}{ Complication after delivery } & Not observed & $6(75.0)$ & $57(83.8)$ & $23(95.8)$ & b0.187 \\
\hline & Bumm curettage & $0(0.0)$ & $7(10.3)$ & $0(0.0)$ & b0.316 \\
\hline & Preterm PROM & $2(25.0)$ & $2(2.9)$ & $0(0.0)$ & bo.038 \\
\hline & Cervical laceration & $0(0.0)$ & $1(1.5)$ & $1(4.2)$ & b0.540 \\
\hline & Chorioamnionitis with fever & $0(0.0)$ & $1(1.5)$ & $0(0.0)$ & b0.999 \\
\hline
\end{tabular}

${ }^{a}$ Kruskal-Wallis test, 'Fisher-Freeman-Halton's exact test, 'Pearson's chi-square test. ${ }^{*} p<0.01,{ }^{\dagger} p<0.05$. PROM: premature rupture of membranes. 
as urethra and bladder have been reported in previous studies. ${ }^{[1]}$

In our cases, no intraoperative complication developed such as bladder injury, bleeding or anesthetic problems. Premature rupture of membrane which can be considered as postoperative complication occurred in 10 patients. Four out of these 10 cases were in the emergency cerclage group.

The complications were observed as statistically and significantly higher in the emergency cerclage group. It is a known reality that the emergency cerclage performed in cases where membranes were prolapsed from cervix has a high risk for adverse events. ${ }^{[12]}$ Our results are in this direction. Especially the patients to be applied emergency cerclage treatment should be informed about the complications that may develop.

In our case series, if the emergency cerclage group is excluded, there is a low rate of fetal loss compared to the series published previously. ${ }^{[13]}$

When we analyze the complications after the procedure such as chorioamnionitis and preterm rupture of membrane, we see that chorioamnionitis developed only in one case. This rate is quite low compared to the rates reported previously. ${ }^{[3,14,15]}$ These positive results bring to mind the efficacy of antibiotic and tocolytic treatment that we used postoperatively. Low infection rates may be attributed to antibiotic use. In our case, as prophylactic, we used nifedipine as a tocolytic agent. The studies performed show that nifedipine is more effective than other agents in acute tocolysis. ${ }^{[16]}$ However, in order to make a suggestion on this matter, wider, prospective, randomized and controlled studies are needed.

Cervical laceration was also observed at a low rate compared to the published data. ${ }^{[17]}$ Our cesarean rates are higher than the series published previously. ${ }^{[1,19]}$ In a series of 54 cases published in Turkey, the cesarean rate was reported as $22 \%$. While the rate of preterm labor reported by the same study was similar to our study, two cases developed chorioamnionitis, one from emergency cerclage group and one from prophylactic cerclage group. ${ }^{[20]}$

\section{Conclusion}

Consequently, while the rates of preterm labor were high in our cases, other complications were observed at a lower rate. However, in order to present the results and complications of cervical cerclage, wider studies

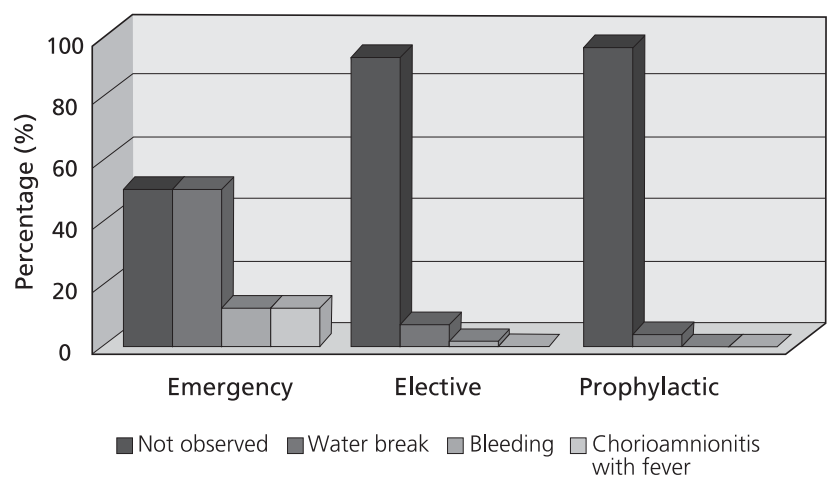

Fig. 3. Complication distribution.

where sub-group analyses are done separately are required.

Today, cervical cerclage should be applied to chosen patients in the presence of informed consent and in consideration of published advantages and complications.

Conflicts of Interest: No conflicts declared.

\section{References}

1. Romero R, Espinoza J, Erez O, Hassan S. The role of cervical cerclage in obstetric practice: can the patient who could benefit from this procedure be identified? Am J Obstet Gynecol 2006;194:1-9.

2. Berghella V, Odibo AO, To MS, Rust OA, Althuisius SM. Cerclage for short cervix on ultrasonography: meta-analysis of trials using individual patient-level data. Obstet Gynecol 2005;106:181-9.

3. Cockwell HA, Smith GN. Cervical incompetence and the role of emergency cerclage. J Obstet Gynaecol Can 2004;27:123-9.

4. Simcox R, Shennan A. Cervical cerclage: a review. Int J Surg 2007;5:205-9.

5. Drakeley AJ, Roberts D, Alfirevic Z. Cervical stitch (cerclage) for preventing pregnancy loss. Cochrane Database Syst Rev 2003;(1):CD003253.

6. Rust OA, Atlas RO, Jones KJ, Benham BN, Balducci J. A randomised trial of cerclage versus no cerclage among patients with ultrasonographically detected second trimester preterm dilatation of the internal os. Am J Obstet Gynecol 2000;182:1086-8.

7. Alfirevic Z, Owen J, Carreras Moratonas E, Sharp AN, Szychowski JM, Goya M. Vaginal progesterone, cerclage or cervical pessary for preventing preterm birth in asymptomatic singleton pregnant women with a history of preterm birth and a sonographic short cervix. Ultrasound Obstet Gynecol 2013;41:146-51. 
8. Conde-Aguledo AC, Romero R, Nicolaides K, Chaiworapongssa T, O’Brien J, Çetingoz E, et al. Vajinal progesterone versus cervical cerclage for the prevention of preterm birth in women with a sonographic short cervix, singleton gestation and previous preterm birth: a systematic review and indirect comparison meta-analysis. Am J Obstet Gynecol 2013;208:38-42.

9. To MS, Palaniappan V, Skenteou C, Gibb D, Nicolaides K. Elective cerclclage vs. ultrasound indicated cerclage in highrisk pregnancies. Ultrasound Obstet Gynecol 2002;19:4757.

10. Khan MJ, Ali G, Al Tajir G, Sulieman H. Evaluation of outcomes associated with placement of elective, urgent, and emergency cerclage. J Obstet Gynaecol India 2012;62:660-4.

11. Harger JH. Comparison of succsess and morbidity in cervical cerclage procedures. Obstet Gynecol 1980;53:543-8.

12. Chasen ST, Silverman NS. Mid-trimester emergent cerclage: a ten year single instititution review. J Perinatol 1998;18:338-42.

13. Seppälä M, Vara P. Cervical cerclage in the treatment of incompetent cervix: a retrospective analysis of the indications and results of 164 operations. Acta Obstet Gynecol Scand 1970;49:343-6.
14. To MS, Alfirevic Z, Heath VCF, Cicero S, Cacho AM, Williamson PR, et al. Cervical cerclage for prevention of preterm delivery in woman with short cervix: randomised controlled trial. The Lancet 2004;363:1849-53.

15. Drassinower D, Poggi SH, Landy HJ, Gilo N, Benson JE, Ghidini A. Perioperative complications of history-indicated and ultrasound-indicated cervical cerclage. Am J Obstet Gynecol 2011;205:53.e1-5.

16. Papatsonis DN, Van Geijn HP, Adèr HJ, Lange FM, Bleker OP, Dekker GA. Nifedipine and ritodrine in the management of preterm labor: a randomized multicenter trial. Obstet Gynecol 1997;90:230-4.

17. Schwartz RP, Chatwani A,Sullivan P. Cevical cerclage. A review of 74 cases. J Reprod Med 1984:29:2:103-6.

18. Mubasshir S, Munim S, Zainab G. Morbidities of cervical cerclage: experience at a tertiary referral center. J Pak Med Assoc 2012;62:603-5.

19. Waloch M. Cervical cerclage in the treatment of cervical incompetence in Zambian women. Clin Exp Obstet Gynecol 1996;23:255-62.

20. Karaca İ, Yapça ÖE, Delibaş İB, İngeç M. Cervical Incompetence: comparison the prophylactic and therapeutic cerclage. Perinatal Journal 2013;21:7-11. 